\title{
Founder Characteristics and Legitimacy-Seeking Behaviors
}

\author{
John T. Perry, Gaylen N. Chandler
}

Xin Yao, Timothy L. Pett

\begin{abstract}
7 he entrepreneur's experience, personality, and values affect the entrepreneur's behaviors and decisions (Chrisman, Bauerschmidt, and Hofer 1998). Past research results show that (1) more experienced new venture founders have a greater likelibood of leading their ventures to early success than less experienced founders (Delmar and Shane 2006) and (2) founders who engage in legitimacy-seeking behaviors have a greater likelibood of leading their ventures to early success than founders who do not do so (Tornikoski and Newbert 2007). We propose that more experienced founders understand the importance of obtaining legitimacy for their ventures and therefore will engage in more legitimacy-seeking behaviors. In addition, we propose that entrepreneurs' growth aspirations and internal locus of control are also associated with engagement in legitimacy-seeking bebaviors. We test and find support for these propositions in a sample of new ventures and their founders.
\end{abstract}

Keywords: founders; entrepreneurial behavior; legitimacy; PSED; entrepreneurial experience

\section{Introduction}

Legitimacy involves the means that organizations use to justify their existence to peer and stakeholder organizations (Suchman 1995). For emerging organizations, marketing a product or service early in a venture's life, projecting financial statements, preparing a business plan, filing a patent, opening a bank account, and/or establishing a new telephone listing for the venture have all been identified as legitimacy-seeking behaviors (Gartner, Shaver, Carter, and Reynolds 2004;Tornikoski and Newbert 2007). Tornikoski and Newbert (2007) demonstrated that founding teams that engaged in legitimacy-seeking behaviors were more likely to make their ventures operational than those that did not. However, the factors that influence legitimacy-seeking behavior have not been examined. What are the factors that are associated with engagement in behaviors that increase the new venture's legitimacy with other stakeholders?

In the current research we focus on both the knowledge base of the founding team and personality characteristics of the lead entrepreneur in an initial attempt to identify and substantiate some of the factors that are associated with engagement in legitimacy-seeking behaviors. Previous research indicates that ventures created by experienced founding teams are more likely to survive and succeed, which suggests that experienced firm founders may have developed their knowledge base by learning what needs to be done to successfully organize a new firm (Delmar and Shane 2006) and substantiates findings that experience and success tend to be positively correlated (e.g., Robinson and Sexton 1994). In addition to knowledge, previous research has shown that growth intentions (Wiklund, Davidsson, and Delmar 2003; Wiklund and Shepherd 2003) and locus of control (Begley Tan, and Schoch 2005) are associated with entrepreneurial activity.

We create a model that includes knowledge, growth intentions, and founder locus of control to explain engagement in legitimacy-seeking behaviors. We contribute to the new venture literature by showing that founding teams with greater entrepreneurial and industry experience, higher growth expectations, and an external locus of control are more likely to engage in legitimacy-seeking behaviors. Both experience and personality characteristics appear to influence engagement in such behaviors.

To accomplish these objectives, we describe an appropriate theoretical perspective, define the key constructs, develop hypotheses, and test the hypotheses with a sample of new ventures and their founders. Subsequently, we present the results and discuss the implications of our research.

\section{Theoretical Perspective}

The arguments that we make in this research are consistent with social cognitive theory (Bandura 1986) and the theory of planned behavior (Ajzen 1991). A key construct in social cognitive theory is self-efficacy. Self-efficacy has been described as the belief that one is capable of performing in a certain manner to attain certain goals and that one has the capabilities to execute the courses of actions required to manage prospective situations. According to social cognitive theory (Bandura 1986), the most powerful ways by which people achieve self-efficacy are via enactive mastery and vicarious experience. In other words, they practice, work, and engage themselves in the behavior until they see some 
success. That success leads to the belief that they will be able to accomplish that task or deal with a similar situation in the future. Alternatively, and perhaps coincidentally, as they watch others accomplish the task successfully, it also enhances their self-efficacy beliefs.

The logic of the development of self-efficacy is consistent with the theory of planned behavior.According to the theory of planned behavior (Ajzen 1991) people are more likely to engage in a specific behavior if they view the behavior as positive, think that others who are important to them want them to engage in that behavior, and have the conviction that they can successfully execute the behavior required to produce the outcomes (self-efficacy).A high correlation between these three conditions has been confirmed in many studies (e.g. Sheppard, Hartwick, and Warshaw 1988). Behavior that we seek to explain in this research is engagement in legitimacy-seeking activities. Thus, individuals who start a business are more likely to engage in legitimacy-seeking behaviors such as marketing a product or service early in a venture's life, projecting financial statements, preparing a business plan, filing a patent, opening a bank account, and/or establishing a new telephone listing for the venture, if they believe that doing so is positive, that other stakeholders expect them to do it, and that their firms will be more successful when they engage in those behaviors.

\section{Key Constructs and Hypotheses Entrepreneurial Experience}

Minniti and Bygrave (2001) indicate that two types of knowledge are particularly relevant to starting a business-knowledge about how to start a company and knowledge about a chosen market (Minniti and Bygrave 2001). Knowledge about how to start a company includes knowledge about "how to be entrepreneurial." Minniti and Bygrave state that this type of knowledge "can be acquired only through learning-bydoing or by direct observation" (2001: 6).

The description of how individuals gain knowledge about how to start a business is also consistent with the development of entrepreneurial self-efficacy.As individuals and teams go through the process of starting a business, they face a variety of issues. These issues include receiving or not receiving financial and emotional support, being or not being taken seriously, securing or not securing health insurance, balancing or not balancing demands for time, and receiving or not receiving mentoring and/or counseling (Brush and Manolova 2004). When faced with these problems, founders search for solutions by engaging in different behaviors in an attempt to solve the problem (Minniti and Bygrave 2001). This process of experimentation requires large amounts of time and effort. But once a founder has satisfactorily solved the problem, she or he will associate their last behavior with the problem and thereby add to their knowledge base of how to start a ven- ture. For example, when faced with the problem of being taken seriously by potential investors, a founder may develop a business plan. If she or he perceives that having developed a business plan helped the venture to be taken more seriously, they will associate the development of a business plan with the problem of being taken seriously by potential investors.

Minniti and Bygrave (2001) argue that knowledge about how to start a venture is more valuable (that is, a superior resource) than knowledge about the chosen market because it can only be acquired via direct experience or observation. Being able to acquire this knowledge only via limited means makes it rarer than if it could be acquired via a variety of means, and therefore potentially more valuable than other types of knowledge. Knowledge about how to start a venture includes knowledge related to problems that new ventures commonly experience that more mature companies do not.

Minniti and Bygrave (2001) further stated that knowledge that founders developed in earlier problems will become embedded in their beliefs and expectations; and therefore, when a founder encounters a similar problem again (for example, in a subsequent venture), to avoid a new search for a solution, the founder will engage in the same behavior (for example, she or he will again develop a business plan).

As we have described here, the learning process described by Minniti and Bygrave (2001) is consistent with the development of self-efficacy. Thus, for individuals who are starting a new venture, prior entrepreneurial experience should be directly and positively associated with the belief that engaging in legitimacy-seeking behaviors is valuable. Thus, we expect that founders who have previously helped start several ventures will have learned that legitimacy-seeking behavior, like early marketing efforts, can help them increase their venture's legitimacy in the eyes of their stakeholders and improve the likelihood of the venture's survival. Therefore, we expect that experienced founding teams will be more likely to engage in more legitimacy-seeking behaviors than founding teams with less entrepreneurial experience.

Hypothesis 1: Founding teams with greater entrepreneurial experience will be more likely to engage in legitimacy-seeking behaviors than teams with less entrepreneurial experience.

\section{Industry Experience}

Minniti and Bygrave (2001) also discuss the importance of gaining knowledge about a chosen market. Knowledge about a chosen industry may be either product or service specific or market specific, and includes knowledge specific to an industry or market, including the norms of behavior in that market. Chandler and Lyon (2009) indicate that this type of knowledge may be acquired through direct experience (that 
is, industry experience), indirect experience (for example, partnering with someone who has industry experience) or from education (for example, attending industry conferences, taking classes).

When starting a venture, a founding team's experience in the venture's industry can provide the venture with knowledge of industry norms and relationships with individuals in the industry who may be potential employees, suppliers, helpers, investors, and customers (Bruderl, Preisendorfer, and Ziegler 1992; Reuber and Fischer 1999; Shane and Stuart 2002). Knowledge of industry norms (for example, how contracts are awarded within the industry, and information about customers' buying cycles) is valuable because it provides a venture's founders with direction in terms of where to focus their energies (Bruderl, et al. 1992; Reuber and Fischer 1999). This knowledge can also help founders behave when interacting with industry stakeholders. Relationships with people in the industry are also valuable because establishing relationships is costly and time consuming, and because developing trust with industry stakeholders is important to engaging in future business relationships (Shane and Stuart 2002). These relationships can help founding teams know with whom they should interact.

We also expect that when they realize the importance of engaging in legitimacy-seeking behavior, because they have greater knowledge of industry norms and have more relationships with industry stakeholders, founders with more industry experience will find it easier to gain legitimacy in the industry.They will know who are likely to be the most important stakeholders for their venture, and they will know what might help their venture appear more favorable in these stakeholders' eyes. Because of this industry-based knowledge, founders who have more industry experience will take less time in the beginning to engage in legitimacy-seeking behaviors than founders who have less industry experience. With reference to the theory of planned behavior, industry knowledge includes information about the expected norms within the industry. Thus, knowing that such behavior is expected by relevant stakeholders would increase the likelihood of engagement in legitimacy-seeking behaviors.

Hypothesis 2: Founding teams with greater industry experience will engage in more legitimacy-seeking behaviors than founding teams with less industry experience.

\section{Intentions for Growth}

Thus far we have used the term "legitimacy-seeking behaviors" to represent actions that are consistent with a founder's seeking to appear credible (i.e., marketing a product or service early in a venture's life, projecting financial statements, preparing a business plan, filing a patent, opening a bank account, and establishing a new telephone listing). We have not, however, examined founders' intentions when engaging in these behaviors. The role of intention as an antecedent to starting a venture has been discussed extensively in the entrepreneurship literature (e.g., Bird 1988; 1992; Crant 1996). A specific case of intention is the degree to which the founders intend to grow their venture. Although, individual intentions are unobservable, Godfrey and Hill (1995) suggest using observable proxies that approximate or are consistent with the unobservable phenomena. One observable characteristic of founders' intentions may be their stated preferences for the future size of their ventures. In a study of nascent entrepreneurs, Dennis and Solomon (2001) found that founders differed in their intentions for the future of their ventures. Some founders intended to grow their ventures into large firms. Some founders intended to develop businesses that provided comfortable lifestyles. Some founders intended to create ventures that provided supplementary income, and some founders intended to keep their ventures afloat until a better opportunity arose. Moreover, in examining how founders translate their ideas into behavior, Bird (1988) argued that

Entrepreneurial intentions, entrepreneurs' states of mind that direct attention, experience, and action toward a business concept, set the form and direction of organizations at their inception. Subsequent organizational outcomes such as survival, development (including written plans), growth, and change are based on these intentions. (442)

Building on Dennis and Solomon (2001) and Bird (1988), we expect that founders who intend to grow their ventures into large firms will engage in different behavior than founders who have different intentions. Wiklund, Davidsson, and Delmar (2003) used a model of the theory of planned behavior (Ajzen 1991) to test attitudes about venture growth. The model has also been applied usefully in several different studies such as decisions concerning choice of detergents, restaurants, automobiles, and blood donation. In our case, we are interested in the specific intention related to expanding a venture. We therefore focus solely on the intentions for growth expressed by the founders. The intention for growth corresponds with the third part of the theory of planned behavior (Ajzen 1991)-the conviction that they can successfully execute the behavior required to achieve the expected growth.

Hypothesis 3: Founding teams with greater aspirations for growth will engage in more legitimacy-seeking behaviors than founding teams with lower growth aspirations. 


\section{Locus of Control}

Locus of control refers to the extent to which individuals believe that they can control the events that affect them (Rotter 1966). Individuals with a high internal locus of control believe that things happen primarily as a result of their own behavior and actions. Those with a high external locus of control believe that other powerful people, chance, and/or fate are the primary influencers of the things that happen. Those with a high internal locus of control have better control of their behavior, tend to exhibit more political behaviors, and are more likely to attempt to influence other people than those with a high external locus of control. They are more likely to assume that their efforts will be successful and they are more active in seeking information and knowledge concerning their situation. The concept of locus of control is related to self-efficacy, but differs because locus of control is generally a measure of cross-situational beliefs about control, while self-efficacy is used as a concept to relate to specific situations and tasks.

In a recent meta-analysis, Rauch and Frese (2007) reported that internal locus of control was positively correlated with business creation and success. In one of the studies included in the meta-analysis, Anderson (1977) argued that this finding was due to the fact that individuals who believe that events that happen in their lives are generally caused by their thoughts and actions assume that they can influence their future, which increases their motivation and their intentions. Building on this explanation, we expect that founders who believe that they can largely influence their venture's future will engage in more legitimacy- seeking behavior than founders who believe their venture's future is largely outside of their control.

Hypothesis 4: Founding teams with an internal locus of control will engage in more legitimacy-seeking behaviors than founding teams with an external locus of control.

\section{Methods}

To test our hypotheses, we used data from the first Panel Survey of Entrepreneurial Dynamics (PSED) dataset. The PSED dataset is composed of 830 individuals who were in the new venture process in the United States when the study began and 431 comparison individuals. The dataset was designed to be representative of the nascent entrepreneur population in the United States between 1998 and 1999. (For more information about the PSED, see Gartner, Shaver, Carter, and Reynolds 2004). To limit our sample to only new ventures, we used kscleans (Shaver 2006), a publicly available SPSS syntax file, to reduce the sample. In using kscleans, we eliminated the comparison individuals and six ventures that should have been screened out of the dataset because they did not qualify as new ventures (that is, at the beginning of the study, the ventures had positive cash flow for more than 90 days). We also eliminated ventures that were spin-offs of other companies (that is, nonpersons owned more than $50 \%$ of the venture). This resulted in a sample of 817 new ventures. Because we wanted to focus on founding teams, as previous research that examined founder experience had done (Delmar and Shane 2006), we eliminated ventures composed of a single founder. Finally, we reduced the sample to eliminate missing data.The final sample that we analyzed included 255 founding teams. To determine whether the founding teams in the final sample were representative of the founding teams that were not included in the sample, we compared the teams based on team size (i.e., the number of founders), the average number of years of industry experience, and the average number of ventures that members helped start. Comparisons of means via independent sample t-tests found no significant differences between the founding teams in the final sample and those not included in the sample.

\section{Variables}

We constructed the dependent variable, percentage of legitimacy-seeking behaviors used, from the six institutionalization PSED items that were answered by the founding team respondent. We coded the percentage of legitimacy-seeking behaviors used as the number of times a respondent answered "yes" to the following questions divided by the number of questions the respondent answered (not including "not applicable" or "don't know"). The PSED item names were Q122, Q137, Q111, Q124, Q160, and Q171. Item Q122 asked, "Have marketing or promotional efforts been started (for the product or service this [startup/ new firm] will be selling)?" Item Q137 asked, "Have projected financial statements, such as income and cash flow statements or breakeven analysis, been developed?" Item Q111 asked whether a business plan had been prepared. Item Q124 asked, "Has an application for a patent, copyright, or trademark relevant to this new business been submitted?" Item Q160 asked, "Has a bank account been opened exclusively for this new business?"And item Q171 asked, "Does the new business have its own listing in the phone book?"

For entrepreneurial experience, we used PSED item Q214, which asked founders how many businesses they and their fellow founding team members had helped start. Because this number would increase with the size of the founding team, we summed the number of businesses that team members had helped start, and divided this number by the number of founders.

For industry experience, we used PSED item Q213, which asked founders how many years of work experience they and their fellow founding team members had in the venture's industry.Again, because this number would increase with the 
size of the founding team, we computed this variable by calculating the average number of years of industry experience for all team members. That is, we summed the team members' years of industry experience, and divided this number by the number of founders.

For growth orientation, we used PSED item Q322, which asked founders to select their preference for the future size of their venture. Founders were forced to select between indicating that they wanted their venture to be "as large as possible" or "a size to manage by self or with key employees." The "as large as possible" selection was coded as " 1 " and the "a size to manage by self or with key employees" was coded as "0." Note that this item was only available for the team's lead founder. Because the PSED data collection team, however, attempted to survey the leaders of founding teams, and because founding teams were generally small (the mean team size $=2.42$ founders), we assumed that the lead founder's growth orientation was representative of the team's growth orientation.

For locus of control, we used PSED items QL1h, QL1i, and QL1j. These items asked founders whether the following statements were completely untrue (coded as " 1 ”), mostly untrue (coded as " 2 "), it depends (coded as " 3 "), mostly true (coded as "4"), or completely true (coded as "5") for themselves. QL1h stated, "I have no trouble making and keeping friends." QL1i stated, "When I make plans I am almost certain to make them work." And, QL1j stated, "When I get what I want, it is usually because I worked hard for it." To develop a single measure of locus of control, we averaged founders' scores across these three items. Like growth aspiration, the locus of control items were only available for the team's lead founder. In addition, because higher answer codes related to an internal locus of control, we labeled the variable in our analysis as internal locus of control.

Although we focus in this article on actions that founding teams take to conform to general new venture creation norms, we recognize that there are norms, regulations, and practices that differ between industries. For example, in industries in which company certifications are important (for example, automobile parts manufacturing industries), specific actions must be taken (for example, complying with certification processes) that provide a venture with a base level of legitimacy (Stouder 2002). To control for industry effects, therefore, we coded each venture's industry using the PSED item SUSECT10 to identify the venture's industry. This item places a venture's industry into one of 10 categories. We excluded the industries that were not represented in the sample (mining, financial services, and public administration). Eight dummy variables were then used to represent whether the venture was in a given sector (i.e. agriculture, forestry, or fish sector; construction sector; manufacturing sector; transportation, communication, or utilities sector; wholesale trade sector; retail trade sector; and services sector). If the venture was in one of these sectors, we coded the industry as 1 ; otherwise we coded it as 0 . Also, because larger founding teams have more individuals who could engage in more legitimacy-seeking behaviors, we controlled for team size. To do so, we used the PSED item TEAMSZ.

\section{Results}

Because of the continuous nature of the dependent variable and because we wanted to control for several variables in our examination of the percentage of legitimacy-seeking behaviors used, we used ordinary least squares regression to test the hypotheses. See Table 1 for descriptive statistics and correlations of the study variables, and Table 2 for the hypothesis testing results.

We show in Table 1 that none of the industry characteristics are significantly correlated with percentage of legitimacy-seeking behaviors used. Team size, entrepreneurial experience, industry experience, growth orientation, and internal locus of control, however, are significantly correlated with the dependent variable $(\mathrm{p}<.10)$. However, internal locus of control is significant in the direction opposite what we initially hypothesized. Nevertheless, these findings provide initial, univariate support for our first three hypotheses, and an interesting discussion point for the fourth. These statistically significant correlations, while all lower than .20, are consistent with the range of effect sizes that Connelly, Ireland, Reutzel, and Coombs (2009) found in a recent metaanalysis of small business studies. In addition to the significant univariate correlations between the independent and dependent variables, team size is also significantly and positively correlated with both entrepreneurial experience and growth orientation. This indicates that more experienced founders and founders who intend to grow their venture into large firms organize themselves into larger founding teams than less experienced founders. In terms of the correlations between the independent variables, we show in Table 1 that entrepreneurial experience is positively and significantly correlated with industry experience $(r=.13)$ and growth orientation $(r=.10)$. This indicates that founding teams with more years of experience in their venture's industry have helped to start more businesses and founding teams that have started more businesses had greater growth aspirations than those that had started fewer businesses. Lastly, in terms of univariate correlations, we show in Table 1 that founders' growth orientations were positively and significantly related to having an internal locus of control. This indicates that founders who intended to grow their ventures the most were more likely to have an internal locus of control.

In Table 2, model 1, we show the results of the dependent variable regressed on the control variables. The only control 
Table 1. Descriptive Statistics and Correlations among Study Variables

\begin{tabular}{|c|c|c|c|c|c|c|c|c|c|c|c|c|c|c|}
\hline Variable & Mean & $\begin{array}{l}\text { Std } \\
\text { Dev }\end{array}$ & 1. & 2. & 3. & 4. & 5. & 6. & 7. & 8. & 9. & 10. & 11. & 12. \\
\hline $\begin{array}{l}\text { 1.Agriculture, forestry, } \\
\text { or fish industry }\end{array}$ & .05 & .21 & & & & & & & & & & & & \\
\hline $\begin{array}{l}\text { 2. Construction } \\
\text { industry }\end{array}$ & .04 & .19 & -.05 & & & & & & & & & & & \\
\hline $\begin{array}{l}\text { 3. Manufacturing } \\
\text { industry }\end{array}$ & .05 & .22 & -.05 & -.05 & & & & & & & & & & \\
\hline $\begin{array}{l}\text { 4. Transportation, } \\
\text { communication, or } \\
\text { utilities industry }\end{array}$ & .03 & .17 & -.04 & -.04 & -.04 & & & & & & & & & \\
\hline 5. Wholesale industry & .03 & .11 & -.04 & -.04 & -.04 & -.03 & & & & & & & & \\
\hline 6. Retail industry & .27 & .44 & $-.13^{*}$ & $-.12^{*}$ & $-.14^{*}$ & $-.11+$ & $-.11+$ & & & & & & & \\
\hline 7. Services industry & .45 & .50 & $-.20^{* * *}$ & $-.18^{* *}$ & $-.21^{* * *}$ & $-.16^{* * *}$ & $-.16^{* * *}$ & $-.54^{* *}$ & & & & & & \\
\hline 8. Team size & 2.42 & .84 & -.05 & -.01 & $.10+$ & -.03 & -.02 & -.09 & .02 & & & & & \\
\hline $\begin{array}{l}\text { 9. Entrepreneurial } \\
\text { experience }\end{array}$ & .98 & 1.63 & -.04 & -.01 & .09 & -.01 & .01 & -.01 & -.06 & $.21^{* * *}$ & & & & \\
\hline 10. Industry experience & 7.38 & 7.39 & .08 & $.23^{* *}$ & .04 & $-.10+$ & -.02 & $-.11+$ & .02 & .04 & $.13^{*}$ & & & \\
\hline 11. Growth orientation & .23 & .42 & -.03 & -.02 & .08 & -.05 & -.05 & .09 & -.06 & $.18^{* * *}$ & $.10+$ & -.01 & & \\
\hline $\begin{array}{l}\text { 12. Internal locus of } \\
\text { control }\end{array}$ & 4.07 & .52 & .07 & .07 & -.03 & .03 & .05 & -.04 & -.01 & .02 & -.02 & .02 & $.13^{*}$ & \\
\hline $\begin{array}{l}\text { 13. Percentage of } \\
\text { legitimacy-seeking } \\
\text { behaviors used }\end{array}$ & .41 & .27 & .01 & -.05 & .03 & .05 & .02 & -.01 & -.09 & $.17^{* * *}$ & $.19^{* *}$ & $.15^{*}$ & $.15^{*}$ & $-.10+$ \\
\hline
\end{tabular}

$+\mathrm{p}<.10,{ }^{*} \mathrm{p}<.05,{ }^{* * *} \mathrm{p}<.01$

variable with a significant beta coefficient is team size $(\mathrm{b}=$ $.17, \mathrm{p}<.01$ ). In model 2 , we show the results of the test for each of our four hypotheses. All variables were entered into the equation simultaneously because the correlations among the variables are weak, thus there is little chance that the results will be distorted because of multicollinearity. Hypothesis 1 states that founding teams with more entrepreneurial experience will engage in more legitimacy-seeking behaviors than founding teams with less entrepreneurial experience. The beta coefficient of entrepreneurial experi- 


\begin{tabular}{|l|c|c|}
\hline \multicolumn{3}{|c|}{ Table 2. Regression Results } \\
\hline \multicolumn{1}{|c|}{ Variable } & Model 1 & Model 2 \\
\hline Agriculture, forestry, or fish industry & .02 & .02 \\
\hline Construction industry & -.04 & -.06 \\
\hline Manufacturing industry & .02 & -.01 \\
\hline $\begin{array}{l}\text { Transportation, communication, } \\
\text { or utilities industry }\end{array}$ & .06 & .08 \\
\hline Wholesale industry & .02 & -.03 \\
\hline Retail industry & .02 & -.01 \\
\hline Team size & $.17^{* * *}$ & .11 \\
\hline Entrepreneurial experience & & $.14^{*}$ \\
\hline Industry experience & & $.15^{*}$ \\
\hline Growth orientation & & $.13^{*}$ \\
\hline Internal locus of control & .199 & 2.602 \\
\hline $\mathrm{N}$ & .033 & .004 \\
\hline R2 & $.12^{*}$ \\
\hline Adjusted R2 & & .105 \\
\hline F (model) & & .065 \\
\hline p (model) & & .005 \\
\hline
\end{tabular}

_p $<.10,{ }^{*} \mathrm{p}<.05,{ }^{* *} \mathrm{p}<.01$

All beta coefficients are standardized.

Dependent variable $=$ Percentage of legitimacy-seeking behaviors used.

ence was positive and significant $(b=.14, p<.05)$. Hypothesis 2 states that founding teams with more industry experience will engage in more legitimacy-seeking behaviors than founding teams with less industry experience. The beta coefficient of industry experience was positive and significant $(b=.15$, $\mathrm{p}<.05)$. Hypothesis 3 states that founding teams with a greater growth orientation will engage in more legitimacyseeking behaviors than founding teams with a lower growth orientation. The beta coefficient of growth orientation was positive and significant $(\mathrm{b}=.13, \mathrm{p}<.05)$. Hypothesis 4 states that founding teams with an internal locus of control will engage in more legitimacy-seeking behaviors than founding teams with an external locus of control. Because locus of control was captured and coded as internal locus of control, we expected a positive relationship between internal locus of control and percentage of legitimacy-seeking behaviors used. The beta coefficient of internal locus of control was negative and significant $(\mathrm{b}=-.12, \mathrm{p}<.05)$. When combining all four hypotheses in a single model, all of the beta coefficients of the independent variables are significant $(p<.05)$ and in the hypothesized directions (except for the beta coefficient associated with internal locus of control) and the overall model fit is also significant $(F=2.602, p=.004)$. In sum, these results provide support for three of our four hypotheses. The fourth hypothesis, referencing internal locus of control, is opposite what we hypothesized.This discrepancy will be discussed further in the following section.

\section{Discussion}

In our search of the new venture literature, we did not find any studies that demonstrated that founding teams' experience or intentions are related to the degree to which they engage in legitimacy-seeking behaviors.Applying the logic of social cognitive theory and the theory of planned behavior, we predicted that the levels of entrepreneurial and industry experience of new ventures' founders and their growth orientations and locus of control would be related to the degree to which they engaged in legitimacy-seeking behavior. The results support our predictions. Consistent with our predictions, founding teams that have, on average, helped start more businesses and have more years of work experience in their venture's industry are more likely to engage in behavior that is aimed at increasing their venture's legitimacy. Also, we found that founding teams with lead founders who intend to grow their ventures into large firms are more likely to engage in behavior that is consistent with trying to increase their venture's legitimacy. In contrast, those who have an internal locus of control are less likely to engage in legitimacy-seeking behaviors.

This contradiction might be explained in two ways. Building on the entrepreneurial locus of control and intentions literature (Anderson 1977; Brockhaus 1975; Hansemark 2003), we expected that founders with an internal locus of control will have different intentions for their ventures than founders with an external locus of control. However, Krueger, Reilly, and Carsud (2000) argued that in addition to being related to greater entrepreneurial growth intentions, an internal locus of control in entrepreneurs reduces the importance of conforming to institutional norms for the entrepreneurs. Thus, consistent with Krueger, Reilly, and Carsud (2000), it appears that founders with an internal locus of control are less susceptible to the institutional norms that indicate what founders should do to appear credible than founders with an external locus of control; and conversely founders with an external locus of control are more susceptible to the institutional, entrepreneurial norms. This greater susceptibility seems to incline founders with an external locus of control to engage in behavior that makes them appear credible.

This seeming contradiction may be a function of restriction of range in the variable. Previous researchers (e.g. Carland, Hoy, Boulton, and Carland 1984) indicate that entrepreneurs typically have a higher internal locus of control than small businessowners, managers, and other groups. In this sample, the mean is 4.07 on a 5-point scale. Therefore, 
although the general concept would suggest that internal locus of control should be positively correlated with legitimacy-seeking behaviors, in this restricted range sample, those that do not score quite as high on the scale are more likely to pursue legitimacy-seeking behaviors.

With the exception of the fourth hypothesis, the results are consistent with our hypotheses. Taken in conjunction with previous researchers' findings that the ventures of more experienced founding teams are more likely to survive and succeed in their early years (Delmar and Shane 2006) and that the ventures of founders who engage in behaviors that seek to gain the legitimacy of influential stakeholders more often become operational (Tornikoski and Newbert 2007), the results of this study suggest that one of the reasons that experienced founders are more successful is because their experience provides them with the knowledge and knowhow to engage in more legitimacy-seeking behavior.

\section{Limitations}

In spite of the results that support our hypotheses, we caution readers to interpret the results in light of the study's limitations. We believe there are four main limitations of our study. The first relates to the argument that knowledge about starting a new venture can be acquired only via direct experience or observation. Although we based our argument on the theory of planned behavior and previous research (Minniti and Bygrave 2001), the argument can be made that entrepreneurial knowledge may also be acquired from indirect methods (e.g., by taking entrepreneurship classes, by attending new venture seminars, by reading startup books). To address this argument, we intended to include predictors of indirect entrepreneurial experience in our study. In fact, the PSED contains data about the number of "different courses, classes, workshops, or seminars" founders have taken related to "starting a business" (item Q168). Unfortunately there were many missing data points for this item in the PSED and it would have reduced our sample size to 88 founder teams, which would have reduced our ability to test our hypotheses adequately. Therefore we chose to preserve the study's statistical power, which meant that we were unable to adequately consider indirect entrepreneurial experience.

The second limitation relates to our arguments that imply that founders with greater entrepreneurial and industry experience have learned more about being an entrepreneur and about their venture's industry than founders with less experience. We agree that length of time is only a rough proxy for knowledge gained; or in other words, greater experience does not necessarily mean greater knowledge. This may be especially true in light of the first limitation, which acknowledges that founders may be able to acquire knowledge in ways other than through direct experience.

The third limitation relates to the amount of variance explained by our analytical models. In Table 2 , in spite of the fact that we have included all of our predictors and the fact that the model fit is significant, the amount of variance in the percentage of legitimacy-seeking behaviors used between founding teams is low $(\mathrm{R} 2=.105$, Adjusted $\mathrm{R} 2=.065)$. Thus, the effects are significant, but the model effect size is not large. However, given the nature of our variables and measures and the fact that we found no other study that examined factors that relate to legitimacy-seeking behaviors, we did not expect large effect sizes.

The fourth limitation relates to our use of industry control variables. Although we acknowledge that industries may differ in their norms, regulations, and practices, the industry categorization scheme that we used may not have captured these differences well. Future researchers could address this limitation by addressing what makes it more important in some industries to seek legitimacy than in others. For researchers who are interested in this topic, we recommend reviewing the managerial discretion research (Hambrick and Finkelstein 1987), which has found that managers differ in the latitude of action that they possess partly as a result of institutional norms that exist in their industry.

\section{Future Research}

For future researchers interested in building on this study, there are four ways by which they may do so. One direct way would be to test the mediation model that we have implied. We have hinted that founders' legitimacy-seeking behavior may mediate the relationship between founders' experience and their venture's early success (for example, surviving for a longer period of time, achieving positive cash flow). To test this model, we recommend that researchers examine ventures that began at roughly the same point in time (to control for the effects of venture age) and that researchers use a longitudinal study design (to allow the measurement of legitimacy-seeking behavior measures to precede the measurement of venture success). We did not test the mediation model in this study because the sample that we used was not composed of ventures that began at roughly the same point in time.

A second way that researchers might build on this study is to answer the question, "What else do experienced entrepreneurs know that makes them successful?" In doing so, researchers may begin, as we did, by addressing one of the common problems that Brush and Manolova (2004) indicated that the founders of new ventures face (that is, receiving financial and emotional support, being taken seriously, securing health insurance, balancing demands for time, and receiving mentoring and counseling). Because more experienced founders may have encountered these problems in earlier ventures, they may have developed pertinent knowledge and learned behavior that less experienced founders do not have. 
Because we tested only a few operationalizations of founders' knowledge and legitimacy- seeking behaviors, a third way future researchers could build on this study is by developing and using other operationalizations. In doing so, examining founders' entrepreneurial and industry experience within a single industry might allow researchers to develop measures of legitimacy-seeking behaviors that are specific to an industry. Industry norms, which may affect legitimacy-seeking behavior, are specific to industries and therefore vary across industry. Entrepreneurial norms, on the other hand, cut across industries. Because we examined new ventures across many industries, we focused on entrepreneurial norms and legitimacy-seeking behavior connected to these norms.

A fourth way to build on this study is to examine how the quality of founders' experiences influence their legitimacyseeking behavior. Previous researchers have suggested that founders may learn differently from successful and failed ventures (Cope 2005; Minniti and Bygrave 2001; Parker 2006; Reuber and Fischer 1999). Therefore, researchers could examine what founders learn from successful and failed ventures, and how that learning relates to their behavior in new ventures. In terms of industry experience, researchers could also examine the relationship between the size of the companies for which founders have worked in the past (within their venture's industry) and their legitimacy-seeking behavior. It may be that founders who have worked for large companies, which may be more buffered from the need to externally legitimate themselves than smaller companies (Perrow 1986), are less likely to engage in legitimacy-seeking behaviors.

\section{Implications}

The main lesson of this study is that in new ventures, founders' experience and intentions are significantly related to the degree to which they engage in legitimacy-seeking behaviors. Coupled with Tornikoski and Newbert's (2007) finding that the degree to which new venture founders engage in legitimacy seeking is positively related to venture performance, this lesson can provide guidance for founders, investors, and entrepreneurship teachers. For founders, the main implications of this study are that there are there are important lessons to be learned from experienced founders about how to make your venture credible, and that it is important to the success of your venture to engage in behaviors that are consistent with legitimacy seeking. Less important is the implication for less experienced founders that they can learn from this study that it might be advantageous for them to partner with more experienced founders. For investors, the main implication of this study is that they should encourage the founders of the ventures in which they invest to engage in legitimacy seeking. This will allow the venture to become successful more quickly and benefit investors. But, at the same time we caution investors to be aware of the tradeoffs that accompany legitimacy seeking. For example, if a founding team begins marketing a product early in a venture's life, they may be wasting time that would be better utilized by developing and refining new products. For entrepreneurship teachers, the main implication of this study is that they should teach their students about why it is important to appear credible when staring a new venture and how appearing credible is related to venture performance. Students who graduate from entrepreneurship classes and who later start new ventures would be well served to understand the importance of legitimacy seeking.

In conclusion, this study contributes to the new venture literature by showing that founding teams that have greater entrepreneurial and industry experience are more likely to engage in legitimacy-seeking behaviors. We argue that this is because they have learned from their experience that legitimacy-seeking behavior is important in starting a new venture and they have learned how to engage in such behavior intentionally. This study, therefore, provides one answer to the question, "What do experienced entrepreneurs know that makes them more successful?"They know the importance of engaging in legitimacy-seeking behavior.

\section{References}

Ajzen, I. (1991). The Theory of Planned Behavior. Organizational bebavior and buman decision processes, 50, $179-211$.

Anderson, C. R. (1977). Locus of Control, Coping Behaviors, and Performance in a Stress Setting:A Longitudinal Study.Journal of Applied Psychology, 62, 446-451.

Bandura,A. (1986). Social foundations of thought and action: A social cognitive theory. Englewood Cliffs, New Jersey: Prentice-Hall.

Begley, T.M., W-L.Tan, and H. Schoch. (2005). Politico-economic factors associated with interest in starting a business. Entrepreneurship Theory and Practice, 29(1), 35-55.

Bird, B. J. 1988. Implementing Entrepreneurial Ideas:The Case for Intention. Academy of Management Review 13(3): $442-453$.

Bird, B. J. 1992. The Operations of Intentions in Time:The Emergence of the New Venture. Entrepreneurship Theory and Practice 17, 11-20. 
Brockhaus, R. H. (1975). IE Locus of Control Scores as Predictors of Entrepreneurial Intentions. Proceedings of the Academy of Management, 35, 433-435.

Bruderl, J., P. Preisendorfer, and R. Ziegler. (1992). Survival Chances of Newly Founded Business Organizations. American Sociological Review, 57, 227-242.

Brush, C. G., and T. S. Manolova. (2004). Start-up Problems. In Handbook of Entrepreneurial Dynamics: The Process of Business Creation. Eds. W. Gartner, K. Shaver, N. Carter, and P. Reynolds. Thousand Oaks, CA: Sage, 273-284.

Carland, J.W., F. Hoy, W. R. Boulton, and J. C. Carland. (1984). Differentiating Entrepreneurs from Small Business Owners: A Conceptualization. Academy of Management Review, 9(2):354-359.

Chandler, G. N., and D. W. Lyon. (2009). Involvement in Knowledge-Acquisition Activities by Venture Team Members and Venture Performance. Entrepreneurship Theory and Practice, 33(3), 571-592.

Chrisman, J. J.,A. Bauerschmidt, and C.W. Hofer. (1998). The determinants of new venture performance:An extended model. Entrepreneurship Theory and Practice, 23(1), 5-29.

Connelly, B. L., R. D. Ireland, C. R. Reutzel, C. R., and J. E. Coombs. (2009).The Power and Effects of Entrepreneurship Research. Entrepreneurship Theory and Practice, 34(1), 131-149.

Cope, J. (2005). Toward a Dynamic Learning Perspective of Entrepreneurship. Entrepreneurship Theory and Practice, 29, 373-397.

Crant, J. M., 1996. The Proactive Personality Scale as a Predictor of Entrepreneurial Intentions. Journal of Small Business Management, 34, 97-108.

Delmar, F., and S. Shane. (2006). Does Experience Matter? The Effect of Founding Team Experience on the Survival and Sales of Newly Founded Ventures. Strategic Organization, 4, 215-247.

Dennis, W. J., and G.T. Solomon. (2001). Changes in the Intention to Grow Over Time. Frontiers for Entrepreneurship Research Wellesley, MA: Babson College.

Hambrick, D. C., and S. Finkelstein. (1987). Managerial Discretion:A Bridge between Polar Views of Organizational Outcomes. Research in Organizational Behavior, 9, 369-406.

Gartner,W. B., K. G. Shaver, N. M. Carter, and P. D. Reynolds. (2004). Handbook of Entrepreneurial Dynamics: The Process of Business Creation. Thousand Oaks, CA: Sage.

Godfrey, P. C., and C.W. L. Hill. (1995). The Problem of Unobservables in Strategic Management Research. Strategic Management Research, 16,519-533.

Hansemark, O. C. (2003). Need for Achievement, Locus of Control, and the Prediction of Start-ups: A Longitudinal Study. Journal of Economic Psychology, 24, 301-319.

Krueger, N. F, M. D. Reilly, and A. L. Carsud. (2000). Competing Models of Entrepreneurial Intentions. Journal of Business Venturing, 15, 411-432.

Minniti, M., and W. Bygrave. (2001).A Dynamic Model of Entrepreneurial Learning. Entrepreneurship Theory and Practice, 25, 5-16.

Parker, S. C. (2006). Learning about the Unknown: How Fast Do Entrepreneurs Adjust their Beliefs? Journal of Business Venturing, 21, 1-26.

Perrow, C. (1986). Complex Organizations: A Critical Essay. 3rd ed. New York: McGraw-Hill.

Rauch,A., and M. Frese. (2007). Let's Put the Person Back into Entrepreneurship Research:A Meta-analysis on the Relationship between Business Owners' Personality Traits, Business Creation, and Success. European Journal of Work and Organizational Psychology, 16, 353-385.

Reuber,A. R. and E. Fischer. (1999). Understanding the Consequences of Founders' Experience. Journal of Small Business Management, 37, 30-45.

Robinson, P .B., and E.A. Sexton (1994). The Effect of Education and Experience on Self-employment Success. Journal of Business Venturing, 9(2):141-156.

Rotter, J. B. (1966). Generalized Expectancies of Internal versus External Control of Reinforcements. Psychological Monographs, 80, 1-28. 
Shane, S., and T. Stuart. (2002). Organizational Endowments and the Performance of University Start-Ups. Management Science, $48,154-170$.

Shaver, K. G. (2006). Kscleans.sps. http://www.cofc.edu/ shaverk/ kscleans06.sps. Accessed August 1, 2007.

Sheppard, B. H., J. Hartwick, and P. R. Warshaw. (1988). The Theory of Reasoned Action:A Meta-analysis of Past Research with Recommendations for Modifications and Future Research. Journal of Consumer Research, 15, 325-343.

Stouder, M. D. (2002).The Capital Structure of Decisions of Nascent Entrepreneurs. Ph.D. dissertation. Rutgers, The State University of New Jersey, Newark.

Suchman, M. C. (1995). Managing legitimacy: Strategic and Institutional Approaches. The Academy of Management Review, (20)3: 571-610.

Tornikoski, E.T., and S. L. Newbert. (2007). Exploring the determinants of organizational emergence:A legitimacy perspective. Journal of Business Venturing, 22,311-335.

Wiklund, J., P. Davidsson, and F. Delmar. (2003). What Do They Think and Feel about Growth? An Expectancy-Value Approach to Small Business Managers'Attitudes toward Growth. Entrepreneurship Theory and Practice 27 (3): 247-269.

Wiklund, J., and D. Shepherd. (2003).Aspiring for, and Achieving Growth:The Moderating Role of Resources and Opportunities. Journal of Management Studies, 40(8): 1919-1941.

\section{Acknowledgment}

The authors would like to thank the Center for Entrepreneurship and the Entrepreneurship Research Associates at Wichita State University for their support.

\section{About the Authors}

\section{NEjE}

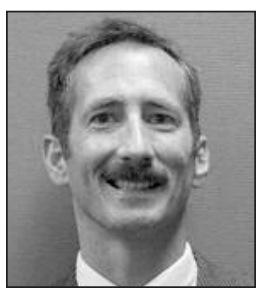

John T. Perry (john.perry@psu.edu) is an assistant professor of strategic management at Wichita State University. He earned his PhD in Management (2006) from the Smeal College of Business at Penn State University. Dr. Perry's research interests include succession issues related to entrepreneurial strategies and family business.

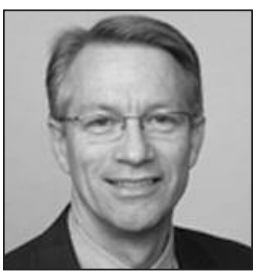

GaYlen N. Chandler (gaylen.chandler@wichita.edu) is a professor of entrepreneurship and the W. Frank Barton Distinguished Chair in Entrepreneurship at Wichita State University. He received his PhD (1990) from the University of Utah. His research interests include opportunity recognition processes, the role of ongoing learning in new venture development, and new venture teams.

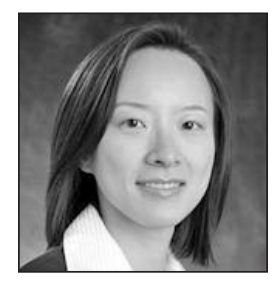

XIN YAO (xin.yao@colorado.edu) is an assistant professor of management and entrepreneurship at the Leeds School of Business, University of Colorado at Boulder. She received her PhD from the University of Washington. Her research interests include with entrepreneur identity and motivation, early stage venture financing, venture capital, and creativity.

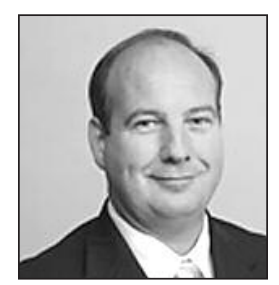

Timothy L. Petr(tim.pett@wichita.edu) is a professor of management, Hayes Company Faculty Fellow, and director of the Center for Entrepreneurship at Wichita State University. He earned his PhD in Strategic Management from the University of Memphis in 1997. Dr. Pett's research interests include small firm performance, innovation, new product development, and international entrepreneurship. 